\title{
HUBUNGAN PENDIDIKAN KESEHATAN MELALUI VIDEO BERBASIS ANDROID DENGAN PENGETAHUAN IBU TENTANG TEKNIK MENYUSUI YANG BENAR DI WILAYAH KERJA PUSKESMAS CIGAYAM TAHUN 2020
}

\section{RELATIONSHIP OF HEALTH EDUCATION THROUGH ANDROID- BASED VIDEO WITH MOTHER'S KNOWLEDGE ABOUT THE CORRECT BREASTFEEDING TECHNIQUES IN THE WORK AREA OF THE CIGAYAM HEALTH CENTER IN 2020}

\author{
Rizka Nurkhofifah ${ }^{{ }^{*}}$, Yudita Ingga Hindiarti ${ }^{2}$ \\ ${ }^{1,2}$ Program Studi D-III Kebidanan, Fakultas Ilmu Kesehatan, Universitas Galuh \\ Jalan R.E Martadinata No.10 Ciamis 46213, Indonesia \\ *E-mail corresponding: rizkanurkhofifa13@gmail.com \\ (Diterima: Maret 2021; disetujui April 2021; dipublish Mei 2021)
}

\begin{abstract}
ABSTRAK
Air Susu Ibu (ASI) merupakan satu jenis makanan yang mencukupi seluruh unsur kebutuhan bayi baik fisik, psikologi, sosial maupun spiritual. Jika ibu tidak memberikan ASI dengan teknik menyusui yang benar diantaranya putting lecet dan ibu mengeluhkan susahnya memberikan. Tujuan penelitian ini untuk mengetahui hubungan pendidikan kesehatan melalui video berbasis android dengan pengetahuan ibu tentang teknik menyusui yang benar di Wilayah Kerja Puskesmas Cigayam Tahun 2020. Metode penelitian ini menggunakan metode deskriptif korelatif dengan pendekatan cross sectional. Pengambilan sampel yang digunakan metode total Sampling. Hasil penelitian menunjukan bahwa diketahui setengahnya dari responden tidak dilakukan pendidikan kesehatan tentang teknik menyusui sebanyak 21 orang $(50 \%)$ dan setengahnya dari responden dilakukan pendidikan kesehatan tentang teknik menyusui sebanyak 21 orang (50\%). sebagian responden memiliki pengetahuan kurang tentang teknik menyusui sebanyak 18 orang $(42,9 \%)$ dan terdapat hubungan antara antara pendidikan kesehatan melalui video berbasis android dengan pengetahuan ibu tentang teknik menyusui yang benar. Responden yang mengikuti pendidikn kesehatan tentang teknik menyusui secara signifikan mempengaruhi pengetahuan ibu hal ini dikarenakan adanya proses pembelajaran melalui media video android. Terdapat hubungan antara antara pendidikan kesehatan melalui video berbasis android dengan pengetahuan ibu tentang teknik menyusui yang benar. Diharapkan Petugas kesehatan dapat lebih meningkatkan promosi kesehatan melalui penyuluhan dan konseling, baik penyuluhan perorangan atau kelompok tentang pengetahuan ibu tentang teknik menyusui yang benar.
\end{abstract}

Kata kunci: Pendidikan Kesehatan, Teknik Menyusui

\begin{abstract}
Mother's Milk (ASI) is a type of food that meets all the elements of a baby's physical, psychological, social and spiritual needs. If the mother does not give breast milk with the correct breastfeeding technique, including sore nipples and the mother complains about the difficulty of giving. The purpose of this study was to determine the relationship of health education through android-based videos with mother's knowledge of correct breastfeeding techniques in the Cigayam Health Center Work Area in 2020. This research method used amethod descriptive correlative with aapproach cross sectional. Sampling used themethod total sampling. The results showed that it was known that half of the respondents did not receive health education on breastfeeding techniques as many as 21 people $(50 \%)$ and half of the respondents received health education on breastfeeding techniques as many as 21 people $(50 \%)$. some respondents have less
\end{abstract}




\section{Rizka Nurkhofifah \& Yudita Ingga Hindiarti}

knowledge about breastfeeding techniques as many as 18 people $(42.9 \%)$ and there is a relationship between health education through android-based videos and mother's knowledge about correct breastfeeding techniques. Respondents who take part in health education about breastfeeding techniques significantly affect mother's knowledge, this is due to the learning process through android video media. There is a relationship between health education through android-based videos and mother's knowledge about correct breastfeeding techniques. It is hoped that health workers can further improve health promotion through counseling and counseling, both individual and group counseling about mother's knowledge about correct breastfeeding techniques.

Keywords: Health Education, Breastfeeding Technique

\section{PENDAHULUAN}

Air Susu Ibu (ASI) adalah satu jenis makanan yang mencukupi seluruh unsur kebutuhan bayi baik fisik, psikologi, sosial maupun spiritual. ASI mengandung nutrisi, hormon, unsur kekebalan faktor pertumbuhan, antialergi serta anti inflamasi. pemberian ASI segera setelah lahir (30 menit pertama bayi harus sudah disusukan) kemudian pemberian ASI saja sampai bayi umur 6 bulan (ASI eksklusif), selanjutnya pemberian ASI sampai 2 tahun dengan pemberian makanan pendamping ASI yang benar.

Masalah yang muncul jika ibu tidak memberikan ASI dengan teknik menyusui yang benar diantaranya adalah putting lecet dan ibu mengeluhkan susahnya memberikan ASI secara langsung, sehingga ibu memberikan ASI dengan cara memompa nya dan dimasukan ke dalam dot, sehingga dengan keluhan tersebut maka akan sulit bagi ibu memberikan ASI secara Eksklusif hal ini menjadi alasan ibu tidak memberikan ASI (Soetjiningsih, 2016).

Permasalahan ini dapat diatasi dengan memberikan ASI dengan teknik menyusui yang benar, Ibu bisa mencoba untuk mengubah posisinya yaitu dengan menghadapkan badan bayi ke badan ibu. Saat
Ibu menyusui bayi, pastikan mulut bayi menutupi sebagian besar areola di bawah puting dibanding bagian atas, posisi ini akan membuat proses Ibu menyusui bayi menjadi lebih nyaman dan tidak terasa sakit. (Roesli, 2015).

Berdasarkan studi pendahuluan yang dilakukan dengan menanyakan kepada petugas Puskesmas Cigayam tentang bagaimana cakupan pemberian ASI Eksklusif di Puskesmas tersebut, didapatkan cakupan pemberian ASI Eksklusif di Puskesmas Cigayam sebanyak 982 bayi (78.2\%) pada tahun 2019 cakupan ini cenderung meningkat dari tahun sebelumnya Tahun 2018 yaitu 911 bayi $(72,5 \%)$ meskipun demikian cakupan ini belum mencapai Standar minimal pelayanan Kesehatan untuk ASI eksklusif yang harus mencapai 1132 bayi (90\%) dari total bayi yang ada di tahun 2019 sebanyak 1255 orang.

Salah satu penggunaan handphone yang paling banyak digunakan oleh masyarakat saat ini yaitu OS Android. Penggunaan handphone dapat digunakan dalam berbagai bidang, termasuk bidang pendidikan. Pada bidang pendidikan pemanfaatan handphone dapat berupa media pembelajaran seperti mobile learning. Mobile learning merupakan suatu media pembelajaran yang bersifat portable atau 
dapat dibawa kemana saja. Media pembelajaran berbasis Android ini juga dapat dibuat dan dikembangkan secara menarik untuk memancing rasa ketertarikan terhadap materi yang disampaikan.

\section{METODE PENELITIAN}

Metode penelitian ini menggunakan metode penelitian deskriptif korelatif dengan pendekatan cross sectional. Populasi yang diambil dalam penelitian ini adalah ibu nifas (Januari- April 2020) sebanyak 42 orang. Pengambilan sampel yang digunakan dalam penelitian ini adalah metode total Sampling dimana jumlah populasi semua dijadikan sempel, yaitu ibu nifas yang ada Di Wilayah Kerja Puskesmas Cigayam Tahun 2020, Jadi sempel yang dibutuhkan dalam penelitian ini adalah sebanyak 21 orang yang dilakukan Pendidikan kesehatan dan 21 orang yang tidak diberikan pendidikan kesehatan.

\section{HASIL PENELITIAN DAN}

\section{PEMBAHASAN}

\section{Tabel 1}

Distribusi Frekuensi Responden

Berdasarkan Pelaksanaan Pendidikan

Kesehatan Tentang Teknik Menyusui Melalui Video Berbasis Android di Wilayah Kerja Puskesmas Cigayam Tahun 2020

\begin{tabular}{ccc}
$\begin{array}{c}\text { Pendidikan } \\
\text { Kesehatan }\end{array}$ & F & \% \\
\hline $\begin{array}{c}\text { Tidak } \\
\text { dilakukan }\end{array}$ & 21 & 50 \\
Dilakukan & 21 & 50 \\
\hline Total & $\mathbf{4 2}$ & $\mathbf{1 0 0}$
\end{tabular}

Dari tabel 1 distribusi frekuensi responden berdasarkan pelaksanaan pendidikan kesehatan melalui video berbasis android diketahui setengahnya dari responden tidak dilakukan pendidikan kesehatan tentang teknik menyusui sebanyak 21 orang $(50 \%)$ dan setengahnya dari responden dilakukan pendidikan kesehatan tentang teknik menyusui sebanyak 21 orang $(50 \%)$.

Tabel 2

Distribusi Frekuensi Responden Berdasarkan Pengetahuan Ibu Tentang Teknik Menyusui Yang Benar di Wilayah Kerja Puskesmas Cigayam Tahun 2020

\section{Pengetahuan Ibu}

Tentang Teknik

Menyusui Sebelum

Dilakukan

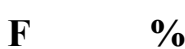

Pendidikan

Kesehatan

\begin{tabular}{|c|c|c|}
\hline Baik & 9 & 21,4 \\
\hline Cukup & 15 & 35,7 \\
\hline Kurang & 18 & 42,9 \\
\hline Total & 42 & 100 \\
\hline
\end{tabular}

Dari tabel 2 distribusi frekuensi responden berdasarkan pengetahuan tentang teknik menyusui diketahui sebagian kecil responden memiliki pengetahuan baik tentang teknik menyusui sebanyak 9 orang $(21,4 \%)$, hampir sebagian responden memiliki pengetahuan cukup sebanyak 15 orang $(35,7 \%)$ dan hampir sebagian responden memiliki pengetahuan kurang tentang teknik menyusui sebanyak 18 orang $(42,9 \%)$. 
Tabel 3

Distribusi Frekuensi Responden Berdasarkan Pendidikan Kesehatan Melalui Video Berbasis Android Dengan Pengetahuan Ibu Tentang Teknik Menyusui Yang Benar di Wilayah Kerja Puskesmas Cigayam Tahun 2020

\begin{tabular}{|c|c|c|c|c|c|c|c|}
\hline \multirow{3}{*}{ Pengetahuan Ibu } & \multicolumn{4}{|c|}{ Pendidikan Kesehatan } & \multirow{2}{*}{\multicolumn{2}{|c|}{ Total }} & \multirow{3}{*}{$\begin{array}{c}\text { P } \\
\text { Value }\end{array}$} \\
\hline & \multicolumn{2}{|c|}{$\begin{array}{c}\text { Tidak } \\
\text { Dilakukan } \\
\end{array}$} & \multicolumn{2}{|c|}{ Dilakukan } & & & \\
\hline & f & $\%$ & $\mathbf{F}$ & $\%$ & $\mathbf{F}$ & $\%$ & \\
\hline Baik & 2 & 9,5 & 7 & 33,3 & 9 & 21,4 & \multirow{4}{*}{$\mathbf{0 , 0 3 1}$} \\
\hline Cukup & 6 & 28,6 & 9 & 42,9 & 15 & 35,7 & \\
\hline Kurang & 13 & 61,9 & 5 & 23,8 & 18 & 42,9 & \\
\hline Total & 21 & 100 & 21 & 100 & 42 & 100 & \\
\hline
\end{tabular}

Berdasarkan tabel 3 dapat dilihat bahwa dari 21 responden yang tidak dilakukan pendidikan kesehatan melalui video berbasis android, didapatkan bahwa sebagian kecil responden memiliki pengetahuan baik tentang teknik menyusui sebanyak 2 orang $(9,5 \%)$, hampir sebagian responden memiliki pengetahuan cukup sebanyak 6 orang $(28,6 \%)$ dan sebagian besar memiliki pengetahuan kurang tentang teknik menyusui sebanyak 13 orang $(61,9 \%)$.

Sedangkan dari 21 responden yang dilakukan pendidikan kesehatan melalui video berbasis android, didapatkan hampir sebagian responden memiliki pengetahuan baik tentang teknik menyusui sebanyak 7 orang $(33,3 \%)$, hampir sebagian responden memiliki pengetahuan cukup sebanyak 9 orang $(42,9 \%)$ dan sebagian kecil responden memiliki pengetahuan kurang tentang teknik menyusui sebanyak 5 orang $(23,8 \%)$.

Berdasarkan hasil uji statistik dengan mengunakan Chi Square, diketahui bahwa nilai $\mathrm{P}(0,031)$ lebih kecil dari nilai $\alpha(0,05)$, sehingga dapat disimpulkan bahwa terdapat hubungan antara antara pendidikan kesehatan melalui video berbasis android dengan pengetahuan ibu tentang teknik menyusui yang benar.

\section{Pembahasan}

Pendidikan kesehatan adalah suatu penerapan konsep pendidikan di dalam bidang kesehatan. Pendidikan kesehatan merupakan suatu kegiatan untuk memberikan atau meningkatkan pengetahuan masyarakat dalam memelihara dan meningkatkan kesehatan. Konsep dasar pendidikan merupakan suatu proses belajar. Hal ini berarti di dalam pendidikan itu terjadi proses perkembangan atau perubahan ke arah yang lebih dewasa, lebih baik dan lebih matang pada diri individu, kelompok atau masyarakat, dari tidak tahu tentang nilai-nilai kesehatan (Notoatmodjo, 2015:106).

Dari tabel 1 distribusi frekuensi responden berdasarkan pelaksanaan pendidikan kesehatan melalui video berbasis android diketahui setengahnya dari responden tidak dilakukan pendidikan kesehatan tentang teknik menyusui sebanyak 21 orang $(50 \%)$ dan setengahnya dari responden dilakukan pendidikan kesehatan 
tentang teknik menyusui sebanyak 21 orang $(50 \%)$.

Berdasarkan hasil penelitian diatas diketahui setengahnya dari responden tidak dilakukan pendidikan kesehatan tentang teknik menyusui dan setegahnya lagi dilakukan pendidikan kesehatan tentang teknik menyusui melalui Video Berbasis Android hal ini disebabkan karena sebagian besar ibu belum memahami jika sebelum menyusui, berbaringlah selama 10-15 menit dan tenangkan pikiran. Perasaan marah, jengkel, atau tegang akan mempengaruhi produksi ASI sehingga hanya keluar sedikit. ASI dibentuk di dalam kelenjar-kelenjar susu jauh di dalam payudara, kemudian dibawa oleh saluran-saluran kecil ke tempat areola, yaitu lingkaran yang berwarna gelap di sekeliling luar putting. Oleh karena itu, jika bayi hanya menghisap di putting saja maka ASI yang keluar tidak cukup banyak.

Teknik menyusui adalah cara memberikan ASI kepada bayi dengan perlekatan dan posisi ibu dan bayi dengan benar (Dardiana, 2014). Memberi ASI dalam suasana yang santai bagi ibu dan bayi. Buat kondisi ibu senyaman mungkin. Selama beberapa minggu pertama, bayi perlu diberi ASI setiap 2,5 -3 jam sekali. Menjelang akhir minggu ke enam, sebagian besar kebutuhan bayi akan ASI setiap 4 jam sekali. Jadwal ini baik sampai bayi berumur antara 10-12 bulan. Pada usia ini sebagian besar bayi tidur sepanjang malam sehingga tidak perlu lagi memberi makan di malam hari (Saryono, 2016: 122).
Dari hasil diatas juga diketahui setengahnya dari responden dilakukan pendidikan kesehatan tentang teknik menyusui disebabkan bahwa pendidikan kesehatan merupakan usaha membantu individu mengontrol kesehatannya sendiri dengan mempengaruhi, menguatkan keputusan atau tindakan yang sesuai dengan nilai dan tujuan mereka sendiri. Nilai pendidikan turun-naik bersama tingkat pengetahuan yang diperoleh, dan daya upaya pendidikan penting pada orang yang pengetahuannya masih rendah.

Peran bidan dalam pemberian pendidikan kesehatan tentang teknik menyusui dalam hal ini adalah, bahwa bidan sebagai fasilitator dala bidang kesehatan memiliki peranan menberika informasi kepada ibu nifas untuk memberikan informasi yangbaik dan benar tentang teknik menyusui, sehingga dengan begitu diharappkan dengan meningkatnya pengetahuan akan meningkatkan pemberian ASI pada bayi oleh ibu nifas.

Penelitian ini ditunjang oleh penelitian yang dilakukan oleh Ratna Yuliati (2018), tentang Studi Deskriptif Praktik Menyusui Pada Ibu Post SC Setelah Dilakukan Pendidikan Kesehatan Dengan Metode Demonstrasi Dan Video Berbasis Android menyebutkan bahwa penggunaan video android dalam Pembelajaran dengan melihat, mendengar, Responden lebih banyak menyerap materi dan mengingat kembali sebanyak 90\% materi yang diberikan melalui video android. 
Dari tabel 2 distribusi frekuensi responden berdasarkan pengetahuan tentang teknik menyusui diketahui sebagian kecil responden memiliki pengetahuan baik tentang teknik menyusui sebanyak 9 orang $(21,4 \%)$, hampir sebagian responden memiliki pengetahuan cukup sebanyak 15 orang $(35,7 \%)$ dan hampir sebagian responden memiliki pengetahuan kurang tentang teknik menyusui sebanyak 18 orang $(42,9 \%)$

Berdasarkan hasil penelitian diatas maka dapat diketahui hampir sebagian responden memiliki pengetahuan kurang tentang teknik menyusui hal ini dikarenakan responden belum mengetahui dengan baik tentang cara menyusui yang benar dan juga manfaat menyusui yang benar, sehingga ibu memiliki kesadaran untuk memberikan ASI secara benar, meningkatkan daya tahan tubuh, jalinan kasih sayang (bonding), dan meningkatkan kecerdasan. Bagi ibu dapat mengurangi pendarahan pos partum (paska melahirkan)

Notoatmodjo (2015) menjelaskan bahwa tujuan penggunaan media antara lain adalah untuk menimbulkan minat sasaran pendidikan, mencapai sasaran yang lebih banyak, membantu mengatasi hambatan dalam pemahaman, merangsang sasaran pendidikan untuk melaksanakan pesan-pesan kesehatan, membantu sasaran pendidikan untuk belajar lebih banyak dan cepat, merangsang sasaran pendidikan untuk meneruskan pesan-pesan yang diterima kepada orang lain, mempermudah penyampaian bahan pendidikan/informasi oleh para pendidik/pelaku pendidikan, mempermudah penerimaan informasi oleh sasaran pendidikan, mendorong keinginan orang untuk mengetahui kemudian lebih mendalami dan akhirnya memberikan pengertian yang lebih baik, membantu menegakkan pengertian yang diperoleh.

Berdasarkan tabel 3 dapat dilihat bahwa dari 21 responden yang tidak dilakukan pendidikan kesehatan melalui video berbasis android, didapatkan bahwa sebagian kecil responden memiliki pengetahuan baik tentang teknik menyusui sebanyak 2 orang (9,5\%), hampir sebagian responden memiliki pengetahuan cukup sebanyak 6 orang $(28,6 \%)$ dan sebagian besar memiliki pengetahuan kurang tentang teknik menyusui sebanyak 13 orang $(61,9 \%)$.

Berdasarkan hasil penelitian diatas maka dapat diketahui sebagian besar memiliki pengetahuan kurang tentang teknik menyusui, hal ini disebabkan kurangnya pemahaman ibu tentang pentingnya menyusui bayinnya, selain itu sebagian besar memiliki pengetahuan kurang tentang teknik menyusui, hal ini juga disebabkan ketidak tahuan tentang nilai-nilai kesehatan menjadi tahu, dari tidak mampu mengatasi masalah kesehatan menjadi mampu mengatasi masalah kesehatan. Konsep ini berangkat dari asumsi bahwa manusia sebagai makhluk sosial dalam kehidupannya untuk mencapai nilai-nilai hidup di dalam masyarakat selalu memerlukan bantuan orang lain yang lebih dewasa.

\section{SIMPULAN}

Diketahui setengahnya dari responden tidak dilakukan pendidikan kesehatan tentang 
teknik menyusui sebanyak 21 orang $(50 \%)$ dan setengahnya dari responden dilakukan pendidikan kesehatan tentang teknik menyusui sebanyak 21 orang (50\%). sebagian kecil responden memiliki pengetahuan baik tentang teknik menyusui sebanyak 9 orang $(21,4 \%)$, hampir sebagian responden memiliki pengetahuan cukup sebanyak 15 orang $(35,7 \%)$ dan hampir sebagian responden memiliki pengetahuan kurang tentang teknik menyusui sebanyak 18 orang $(42,9 \%)$. Diketahui bahwa nilai $\mathrm{P}$ $(0,031)$ lebih kecil dari nilai $\alpha(0,05)$, sehingga dapat disimpulkan bahwa terdapat hubungan antara antara pendidikan kesehatan melalui video berbasis android dengan pengetahuan ibu tentang teknik menyusui yang benar.

\section{DAFTAR PUSTAKA}

Dardiana, A. E., Mifbakhudin, M., \& Mustika, D. N. (2014). Hubungan Antara Pendidikan, Pekerjaan dan Pengetahuan Ibu dengan Teknik Menyusui Yang Benar di Desa Leteh Kecamatan Rembang Kabupaten Rembang. Jurnal Kebidanan, 3(2), 2025.

Notoatmodjo. S., 2015, Promosi Kesehatan, Penerbit Rineka Cipta, Jakarta.

Notoatmodjo. S., 2015, Metodologi Penelitian Kesehatan, Penerbit Rineka Cipta, Jakarta

Saryono, 2016. Asuhan Kebidanan Pada Ibu Nifas. Jakarta: Salemba Medika
Suarca, K., Soetjiningsih, S., \& Ardjana, I. E. (2016). Kecerdasan majemuk pada anak. Sari Pediatri, 7(2), 85-92.

Yuliati, R. (2018). Studi Deskriptif Praktik Menyusui Pada Ibu Post SC Setelah Dilakukan Pendidikan Kesehatan Dengan Metode Demonstrasi Dan Video Berbasis Android Di Rsi Kendal (Doctoral dissertation, Universitas Muhammadiyah Semarang). 
Rizka Nurkhofifah \& Yudita Ingga Hindiarti 